Article

\title{
The Spatial Variation of Dust Particulate Matter Concentrations during Two Icelandic Dust Storms in 2015
}

\author{
Pavla Dagsson-Waldhauserova ${ }^{1,2,3, *}$, Agnes Ösp Magnusdottir ${ }^{1}$, Haraldur Olafsson ${ }^{2,4}$ and \\ Olafur Arnalds ${ }^{1}$
}

1 Faculty of Environmental Sciences, Agricultural University of Iceland, Keldnaholt, Reykjavik 112, Iceland; agnes@lbhi.is (A.Ö.M.); oa@lbhi.is (O.A.)

2 Faculties of Physical and Earth Sciences, University of Iceland, Reykjavik 101, Iceland; haraldur@vedur.is

3 Faculty of Environmental Sciences, Czech University of Life Sciences, Prague 165 21, Czech Republic

4 Icelandic Meteorological Office, Reykjavik 108, Iceland

* Correspondence: pavla@hi.is or pavla@lbhi.is or waldhauserova@fzp.czu.cz; Tel.: +354-433-5000

Academic Editor: Rebecca Sheesley

Received: 14 March 2016; Accepted: 26 May 2016; Published: 3 June 2016

\begin{abstract}
Particulate matter mass concentrations and size fractions of $\mathrm{PM}_{1}, \mathrm{PM}_{2.5}, \mathrm{PM}_{4}, \mathrm{PM}_{10}$, and $\mathrm{PM}_{15}$ measured in transversal horizontal profile of two dust storms in southwestern Iceland are presented. Images from a camera network were used to estimate the visibility and spatial extent of measured dust events. Numerical simulations were used to calculate the total dust flux from the sources as 180,000 and 280,000 tons for each storm. The mean $\mathrm{PM}_{15}$ concentrations inside of the dust plumes varied from 10 to $1600 \mu \mathrm{g} \cdot \mathrm{m}^{-3}\left(\mathrm{PM}_{10}=7\right.$ to $\left.583 \mu \mathrm{g} \cdot \mathrm{m}^{-3}\right)$. The mean $\mathrm{PM}_{1}$ concentrations were $97-241 \mu \mathrm{g} \cdot \mathrm{m}^{-3}$ with a maximum of $261 \mu \mathrm{g} \cdot \mathrm{m}^{-3}$ for the first storm. The $\mathrm{PM}_{1} / \mathrm{PM}_{2.5}$ ratios of $>0.9$ and $\mathrm{PM}_{1} / \mathrm{PM}_{10}$ ratios of $0.34-0.63$ show that suspension of volcanic materials in Iceland causes air pollution with extremely high $\mathrm{PM}_{1}$ concentrations, similar to polluted urban areas in Europe or Asia. Icelandic volcanic dust consists of a higher proportion of submicron particles compared to crustal dust. Both dust storms occurred in relatively densely inhabited areas of Iceland. First results on size partitioning of Icelandic dust presented here should challenge health authorities to enhance research in relation to dust and shows the need for public dust warning systems.
\end{abstract}

Keywords: fine dust; Arctic desert; close-to-ultrafine natural particles; volcanic ash

\section{Introduction}

Air pollution from natural sources accounts for a significant part of the total particulate matter pollution on Earth. Deserts, stratovolcanoes, and arable land areas contribute to global air pollution in addition to emissions from industrialized and densely inhibited regions. Desert dust has a remarkable influence on Earth's ecosystems as well as human health. Several studies have shown that suspended desert dust can increase mortality hundreds of kilometers downwind from dust sources [1-6]. Mortality was found to increase by $2 \%-12 \%$ with every $10 \mu \mathrm{g} \cdot \mathrm{m}^{-3}$ increase in particulate matter $\left(\mathrm{PM}_{10}\right)$ concentration. Some of these studies reported increased mortality for the $\mathrm{PM}_{2.5}$ dust particulate matter. A decrease of mixing layer height was associated with an increase of daily mortality while the effect of mixing layer thinning on particle toxicity was exacerbated when Saharan dust outbreaks occurred [7]. Positive associations between mass concentrations of larger sizes of particles, such as $\mathrm{PM}_{15}$, were observed for cardiopulmonary and ischemic heart disease causes of death during the long-term studies on air pollution and mortality of the American Cancer Society [8]. The studies on levels and speciation of $\mathrm{PM}_{1}$ in Europe are, however, scarce [9-11]. The $\mathrm{PM}_{1}$ fraction has considerable importance in relation to health because of high potential for entering the lungs [12]. Moreover, 
submicron particles are more likely to travel further distances during the long range transport than larger particles [13].

In spite of a cold and moist climate, Iceland has been identified as the most active and largest Arctic and European desert [14]. Other cold climate and high latitudes regions with considerable dust inputs are Alaska, Greenland, Svalbard, Antarctica, and South America [15-20]. One of the most extreme wind erosion events on Earth was measured in Iceland in 2010 [21]. Annual dust day frequency in Iceland is comparable to the major desert areas of the world [22,23]. Emissions from local dust sources, enhanced by strong winds, affect regional air quality in Iceland, such as in the capital Reykjavik [24]. Particulate Matter $\left(\mathrm{PM}_{10}\right)$ concentrations during dust events in Reykjavik often exceed the health limit of $50 \mu \mathrm{g} \cdot \mathrm{m}^{-3}$ over $24 \mathrm{~h}[25,26]$, while $\mathrm{PM}_{10}$ concentrations measured during dust events in the vicinity of dust sources $(<30 \mathrm{~km})$ exceed the health limit in order of 10-100 times [26-28]. This shows that atmospheric aerosols, mainly dust, can markedly impair air quality in non-polluted Arctic/sub-Arctic regions.

Icelandic dust differs from dust originating from most continental deserts. It is volcanogenic in origin, of basaltic composition, with lower $\mathrm{SiO}_{2}$ proportions $(<50 \%)$ and higher $\mathrm{Al}_{2} \mathrm{O}_{3}, \mathrm{Fe}_{2} \mathrm{O}_{3}$, and $\mathrm{CaO}$ contents than crustal dust $[23,27-29]$. This volcanic dust contains about $80 \%$ volcanic glass with numerous large gas bubbles and massive shards. It is extremely angular with sharp-tipped shards and often with curved and concave shard-faces. Fine pipe-vesicular structures of glass, as known from asbestos, can be also found. All these factors suggest that volcanic dust can be easily suspended and have highly negative effects on human health as concluded by Carlsen et al. [30].

Studies that provide PM mass concentration measurements during dust storms in Iceland are few and limited in scope, excluding research related to volcanic eruptions [23,24,27,28,31]. None of these studies dealt with the size partitioning of the PM components. Here we presented a study on PM source characteristics of volcanic dust during two dust events from different dust sources in Iceland. The emphasis was given to the fine dust fraction of $\mathrm{PM}_{1}$. An effort has been made to measure the transverse horizontal profile of dust storms and estimate the spatial extent of such storms in the terms of PM concentrations, dust load computation, and visibility information obtained from cameras.

\section{Experiments}

\subsection{Instrumentation and Measurement Setup}

Two dust storms were measured in southwestern Iceland in the summer of 2015. Measurements of both storms began after the dust plume was visible from Reykjavík with transverse horizontal profile measurements through the dust plumes. The source area of the first dust event on 15 June 2015 was Landeyjasandur (Storm 1, Figure 1A), about $100 \mathrm{~km}$ from Reykjavík, while the second dust storm on 4 August 2015 originated from the Hagavatn dust source (Storm 2, Figure 1B), about $85 \mathrm{~km}$ distance from Reykjavik.

A mobile instrument, aerosol monitor DustTrak DRX 8533EP, was used to measure particulate matter (PM) mass concentrations at several places within the dust plume. The DustTrak instrument provides measurements of mass concentration from 0.001 to $150 \mathrm{mg} \cdot \mathrm{m}^{-3}$ with the mass fraction concentrations corresponding to $\mathrm{PM}_{1}, \mathrm{PM}_{2.5}, \mathrm{PM}_{4}, \mathrm{PM}_{10}$, and the total $\mathrm{PM}_{15}$. Five minute measurements were made at each stop in the dust plume, consisting of 60 five-second sampling periods. The measurement time was short to allow for travel through the dust storm with measurements at as many places as possible. All measurements were calculated as 5-min averages. The TSI DustTraks have given similar results in parallel measurements of PM mass concentration as Beta attenuation instruments (Thermo ESM Andersen FH 62 I-R) [32]. This instrument has been used in Iceland by the Environmental Agency of Iceland (EAI) since 1996 and we have found good relation between $\mathrm{PM}_{10}$ concentrations obtained by DustTrak DRX and the Thermo ESM. The error range for absolute values for other PM size ranges could be $\pm 10 \%$ [33]. We emphasize that the DustTrak measurements in both storms are complemented by an independent measurement by the Thermo ESM instrument at 
the EAI in Reykjavik $\left(\mathrm{PM}_{10}\right.$ 30-min maxima of about $300 \mu \mathrm{g} \cdot \mathrm{m}^{-3}$ for Storm 1 and about $200 \mu \mathrm{g} \cdot \mathrm{m}^{-3}$ for Storm 2). Measurements for Storm 1 with DustTrak at Keldnaholt (Reykjavik) and Thermo ESM at Grensásvegur (Reykjavik), approx. $5 \mathrm{~km}$ apart are very similar ( $\mathrm{PM}_{10} 30$-min maxima of about $224 \mu \mathrm{g} \cdot \mathrm{m}^{-3}$ vs. $280 \mu \mathrm{g} \cdot \mathrm{m}^{-3}$ at the same time, with the latter being closer to the center of the plume). Similar agreement was found for Storm 2. These numbers indicate that large scale errors sometimes reported for measurements with the TSI DustTraks do not apply here [32,33].
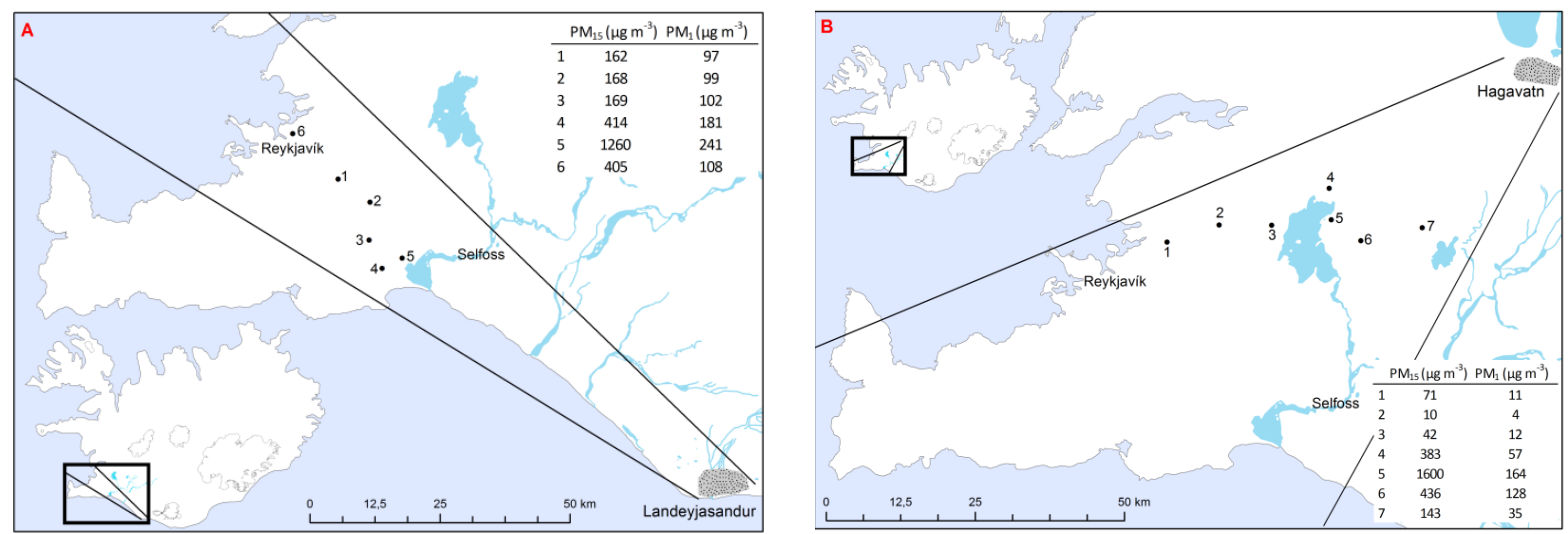

Figure 1. Spatial location of the dust storms. Left figure (A, Storm 1) shows the dust storm from Landeyjasandur on 15 June 2015. The measurement locations are marked on the map with the numbers corresponding to the information on the $\mathrm{PM}_{15}$ and $\mathrm{PM}_{1}$ concentrations in the table. Right figure (B, Storm 2) shows the dust storm from the Hagavatn on 4 August 2015. The lines on the figures depict the dispersal area of the dust plumes estimated from the images of the Icelandic Road and Coastal Administration web camera network [34].

In this study, we used a unique dataset from a network of active cameras operated by the Icelandic Road and Coastal Administration to find the exact extent and area of the dust plume [34]. A total of 25 cameras were used to estimate the visibility changes during these dust storms. Figure 2 presents the time laps images from the web cameras with corresponding visibility estimations. The houses on the photos are situated at about $1 \mathrm{~km}$ from the camera. The mountains in the background are about $3.5 \mathrm{~km}$ from the camera. Subsequently, maps of the dust storms were made in ArcMap 10.1.

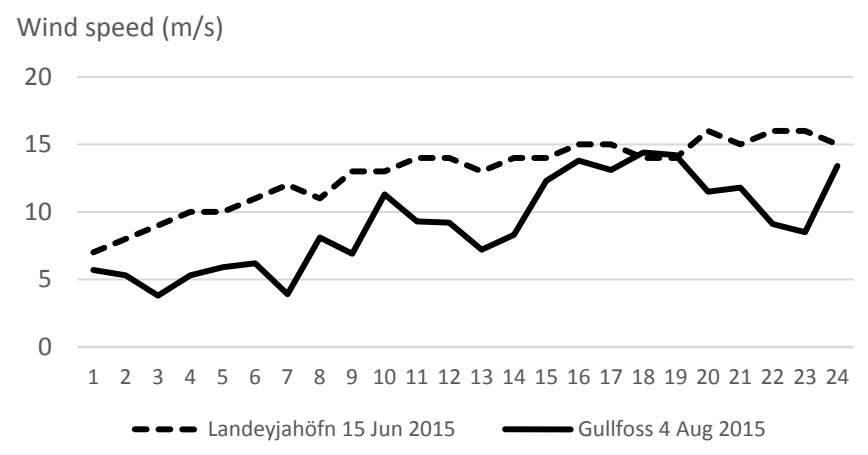

Figure 2. Observations of mean $10 \mathrm{~min}$ wind speed from 01-24 UTC at Landeyjahöfn (at the dust source for Storm 1) on 15 June 2015 and at Gullfoss (about $15 \mathrm{~km} \mathrm{SE}$ of the dust source for Storm 2) on 4 August 2015.

\subsection{Meteorological Conditions and Transport of Dust}

Figure 2 shows the observed 10 min average wind speed at the weather stations Landeyjahöfn (Storm 1), which is close to the dust source, and Gullfoss (Storm 2) which is at a $15 \mathrm{~km}$ distance from 
the source, but does not capture the catabatic wind effects at the source. The wind speed was gradually increasing from about 6 to $16 \mathrm{~m} \cdot \mathrm{s}^{-1}$ during the Landaeyjasandur dust event (Storm 1). The Hagavatn dust event (Storm 2) occurred with wind speeds from about 4 to $14 \mathrm{~m} \cdot \mathrm{s}^{-1}$ measured at Gullfoss. A numerical simulation of surface winds during the two events is shown in Figure 3. The simulation was carried out with the numerical model HIRLAM with a horizontal resolution of $5 \mathrm{~km}$. The simulation was initialized at 00UTC the same day, using initial and boundary conditions from the operational suite at the European Centre for Medium range Weather Forecasts. The true winds in the dust source area on 4 August were probably a few $\mathrm{m} \cdot \mathrm{s}^{-1}$ stronger than observed at Gullfoss. There are substantial horizontal gradients in the wind field close to the dust sources in both cases. In Storm 1 on 15 June, the mountains in S-Iceland generated a corner wind of $6-8 \mathrm{~m} \cdot \mathrm{s}^{-1}$ greater speed than in the incoming flow. This corner wind extended over a large area over the sea and the SW-coast of Iceland. The dust was lifted where this windstorm blew over the coastal areas. Once in suspension, some of the dust entered a wake area over land with weaker winds. In Storm 2 on 4 August, dust was also generated by locally enhanced winds. There was local acceleration in flow which ran along a major mountain range and had a downslope component. The local acceleration and the winds in general were underestimated by a few $\mathrm{m} \cdot \mathrm{s}^{-1}$ in the simulation (Figure 3), but the flow pattern and the wind directions are realistic. The orographic flow perturbation is of a smaller scale in Storm 2 on 4 August than in Storm 1 on 15 June, and consequently is harder to reproduce in a numerical simulation.

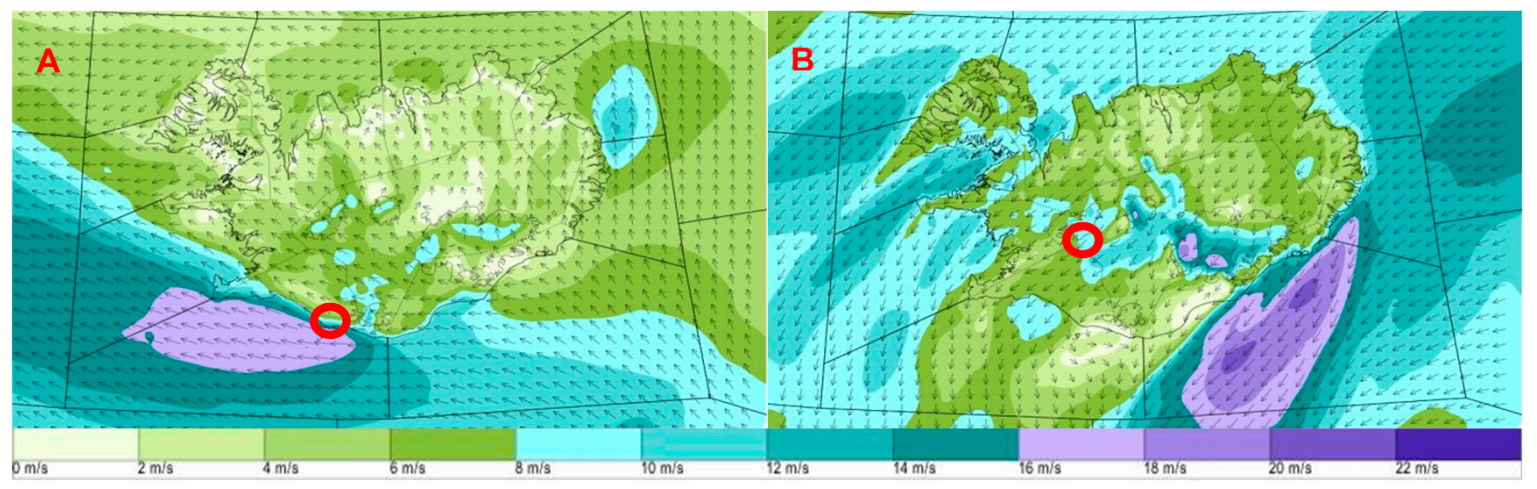

Figure 3. Numerical simulations of $10 \mathrm{~m}$ winds $\left(\mathrm{m} \cdot \mathrm{s}^{-1}\right)$ over Iceland at 15 UTC on (A) Storm 1 on 15 June 2015 and (B) Storm 2 on 4 August 2015. The locations of the dust sources are indicated with a circle.

\section{Results and Discussion}

\subsection{Dust Concentrations and Visibility}

The spatial extent and PM concentrations measured during the two dust storms are shown in Figure 1 and Table 1. The mean $\mathrm{PM}_{15}$ concentrations inside the dust plume 1 varied from $162 \mu \mathrm{g} \cdot \mathrm{m}^{-3}$ to $1260 \mu \mathrm{g} \cdot \mathrm{m}^{-3}\left(\mathrm{PM}_{10}=158-583 \mu \mathrm{g} \cdot \mathrm{m}^{-3}\right)$, and from $10 \mu \mathrm{g} \cdot \mathrm{m}^{-3}$ to $1600 \mu \mathrm{g} \cdot \mathrm{m}^{-3}\left(\mathrm{PM}_{10}=7-486 \mu \mathrm{g} \cdot \mathrm{m}^{-3}\right)$ inside dust plume 2, respectively. These numbers represent rather low concentrations for an ongoing dust storm compared to the long term PM measurements provided by the Environmental Agency of Iceland (EAI) [23,26-28]. This was partly caused by moderate winds not exceeding $16 \mathrm{~m} \cdot \mathrm{s}^{-1}$ (Figures 2 and 3). The mean $\mathrm{PM}_{1}$ concentrations were, however, $97-241 \mu \mathrm{g} \cdot \mathrm{m}^{-3}$ during Storm 1 and reached up to $164 \mu \mathrm{g} \cdot \mathrm{m}^{-3}$ during Storm 2. Such high fine dust concentrations have been reported during massive dust storms from lacustrine sediment areas in Iran and during African dust episodes in Barcelona (hourly means $60-70 \mu \mathrm{g} \cdot \mathrm{m}^{-3}$ ) $[10,35]$. The $\mathrm{PM}_{1}$ maximum of $261 \mu \mathrm{g} \cdot \mathrm{m}^{-3}$ measured during moderate Icelandic dust storms is comparable to the maximum of $495 \mu \mathrm{g} \cdot \mathrm{m}^{-3}$ reported from Iran during a massive dust storm when $\mathrm{PM}_{10}$ concentrations exceeded $5000 \mu \mathrm{g} \cdot \mathrm{m}^{-3}$. Relatively high $\mathrm{PM}_{1}$ annual means are regularly measured over Greece during African dust outbreaks [36]. 
Table 1. Particulate matter concentrations $\mathrm{PM}_{1-15}\left(\mu \mathrm{g} \cdot \mathrm{m}^{-3}\right)$ for both storms. Ratios between different $\mathrm{PM}$ values are given

\begin{tabular}{|c|c|c|c|c|c|c|c|c|c|c|c|}
\hline & $\begin{array}{c}\mathrm{PM}_{1} \\
\text { Average }\end{array}$ & $\begin{array}{c}\mathrm{PM}_{2.5} \\
\text { Average }\end{array}$ & $\begin{array}{c}\mathrm{PM}_{4} \\
\text { Average }\end{array}$ & $\begin{array}{c}\mathrm{PM}_{10} \\
\text { Average }\end{array}$ & $\begin{array}{c}\text { Total }\left(\mathrm{PM}_{15}\right) \\
\text { Average }\end{array}$ & $\begin{array}{c}\mathrm{PM}_{1} / \mathrm{PM}_{10} \\
\text { Ratio }\end{array}$ & $\begin{array}{c}\mathrm{PM}_{2.5} / \mathrm{PM}_{10} \\
\text { Ratio }\end{array}$ & $\begin{array}{l}\mathrm{PM}_{1} / \mathrm{PM}_{2.5} \\
\text { Ratio }\end{array}$ & $\begin{array}{c}\mathrm{PM}_{1} / \mathrm{PM}_{4} \\
\text { Ratio }\end{array}$ & $\begin{array}{l}\mathrm{PM}_{4} / \mathrm{PM}_{10} \\
\text { Ratio }\end{array}$ & $\begin{array}{c}\mathrm{PM}_{10} / \mathrm{PM}_{15} \\
\text { Ratio }\end{array}$ \\
\hline \multicolumn{12}{|c|}{ Storm 1} \\
\hline 1 & 97 & 109 & 130 & 158 & 162 & 0.61 & 0.69 & 0.89 & 0.75 & 0.82 & 0.98 \\
\hline 2 & 99 & 110 & 130 & 158 & 168 & 0.63 & 0.70 & 0.90 & 0.76 & 0.82 & 0.94 \\
\hline 3 & 102 & 114 & 137 & 163 & 169 & 0.63 & 0.70 & 0.89 & 0.74 & 0.84 & 0.96 \\
\hline 4 & 181 & 201 & 248 & 354 & 414 & 0.51 & 0.57 & 0.90 & 0.73 & 0.70 & 0.86 \\
\hline 5 & 241 & 263 & 322 & 583 & 1260 & 0.41 & 0.45 & 0.92 & 0.75 & 0.55 & 0.46 \\
\hline 6 & 108 & 118 & 142 & 224 & 405 & 0.48 & 0.53 & 0.92 & 0.76 & 0.63 & 0.55 \\
\hline \multicolumn{12}{|c|}{ Storm 2} \\
\hline 1 & 11 & 12 & 14 & 29 & 71 & 0.48 & 0.53 & 0.92 & 0.76 & 0.63 & 0.55 \\
\hline 2 & 4 & 4 & 5 & 7 & 10 & 0.38 & 0.41 & 0.92 & 0.79 & 0.48 & 0.41 \\
\hline 3 & 12 & 13 & 16 & 29 & 42 & 0.57 & 0.57 & 1.00 & 0.80 & 0.71 & 0.70 \\
\hline 4 & 57 & 61 & 74 & 162 & 383 & 0.41 & 0.45 & 0.92 & 0.75 & 0.55 & 0.69 \\
\hline 5 & 164 & 174 & 206 & 486 & 1600 & 0.35 & 0.38 & 0.93 & 0.77 & 0.46 & 0.42 \\
\hline 6 & 128 & 140 & 177 & 318 & 436 & 0.34 & 0.36 & 0.94 & 0.80 & 0.42 & 0.30 \\
\hline 7 & 35 & 39 & 48 & 87 & 143 & 0.40 & 0.44 & 0.91 & 0.72 & 0.56 & 0.73 \\
\hline
\end{tabular}


The distance of the measurements from the dust sources was $<100 \mathrm{~km}$. The source material contains extremely fine particles. Storm 1 originated from the Landeyjarsandur dust hot spot which mostly consists of fine volcanic material from active volcanic systems such as Eyjafjallajökull and the Katla systems [14]. Figure 1B shows the values for Storm 2 which originated from the Hagavatn glacial floodplain. The Hagavatn dust materials are more crystalline in nature compared to most other Icelandic dust sources [29]. The higher $\mathrm{PM}_{1}$ concentrations during the Storm 1 than Storm 2 can be related to this difference in crystallinity and also to the early suspension in June rather than in August when submicron particles had been already removed.

The camera network from the Icelandic Road and Coastal Administration (IRCA) was used to determine the dispersal area of these two dust storms. Figure 4 depicts a time lapse series of photos from one of these web cameras which is located in Sandskeið near Reykjavík (Point 1 at the Figures $1 \mathrm{~B}$ and $5 \mathrm{~B}$ ). The visibility was reduced down to $1 \mathrm{~km}$ during Storm 2 . The camera is located about $3.5 \mathrm{~km}$ from the mountain and about $1 \mathrm{~km}$ from the house shown in the middle of the photos. The corresponding $\mathrm{PM}_{10}$ concentrations to these visibility reductions can be obtained from DustTrak measurements close to this location for the left image only. The closest instrument (EAI) is located about $20 \mathrm{~km}$ downwind from this camera. The left picture shows the visibility was $>3.5 \mathrm{~km}$ corresponding to the $\mathrm{PM}_{10}$ of $50 \mu \mathrm{g} \cdot \mathrm{m}^{-3}$ by the EAI and $71 \mu \mathrm{g} \cdot \mathrm{m}^{-3}$ measured using the DustTrak instrument at the site. The middle photo shows the visibility was about $3.5 \mathrm{~km}$, corresponding to the $\mathrm{PM}_{10}$ of $70 \mu \mathrm{g} \cdot \mathrm{m}^{-3}$, while the photo on the right shows visibility was about $1 \mathrm{~km}$, corresponding to $\mathrm{PM}_{10}$ of $100 \mu \mathrm{g} \cdot \mathrm{m}^{-3}$. The $\mathrm{PM}_{10}$ concentrations for the middle and right picture at the location of the camera can, therefore, only be retrieved using the visibility-dust formula given by Dagsson-Waldhauserova et al. [23]. This formula is based on the long-term observations of $\mathrm{PM}_{10}$ and visibility in Iceland. Applying the formula to the visibility estimations from the camera, the $\mathrm{PM}_{10}$ concentrations are calculated as $<190 \mu \mathrm{g} \cdot \mathrm{m}^{-3}$ for the left photo, $370 \mu \mathrm{g} \cdot \mathrm{m}^{-3}$ for the middle photo, and $>780 \mu \mathrm{g} \cdot \mathrm{m}^{-3}$ for the photo on the right.

Impaired visibility was observed at all spots where PM measurements were conducted (Figure 5). These images together with the IRCA camera network allowed us to estimate the spatial extent of the dust plumes as depicted in Figure 1. The total land area affected by Storm 1 was about $2450 \mathrm{~km}^{2}$ but $4220 \mathrm{~km}^{2}$ for Storm 2. Numerical simulations and operational radiosoundings at Keflavik revealed the thickness of the well-mixed atmospheric boundary-layer as about $1 \mathrm{~km}$ in Strom 1 on 15 June with mean winds of about $15 \mathrm{~m} \cdot \mathrm{s}^{-1}$. The event lasted for about $8 \mathrm{~h}$, giving a total dust flux from source of about 180,000 tonnes. In Storm 2 on 4 August, the boundary-layer thickness was about 1.3 $\mathrm{km}$ and the mean winds were $12 \mathrm{~m} \cdot \mathrm{s}^{-1}$. This event lasted for about $12 \mathrm{~h}$ and the total flux from the source is estimated to be about 280,000 tonnes. Both events can thus be characterized as medium-sized (e.g., [22,37]).
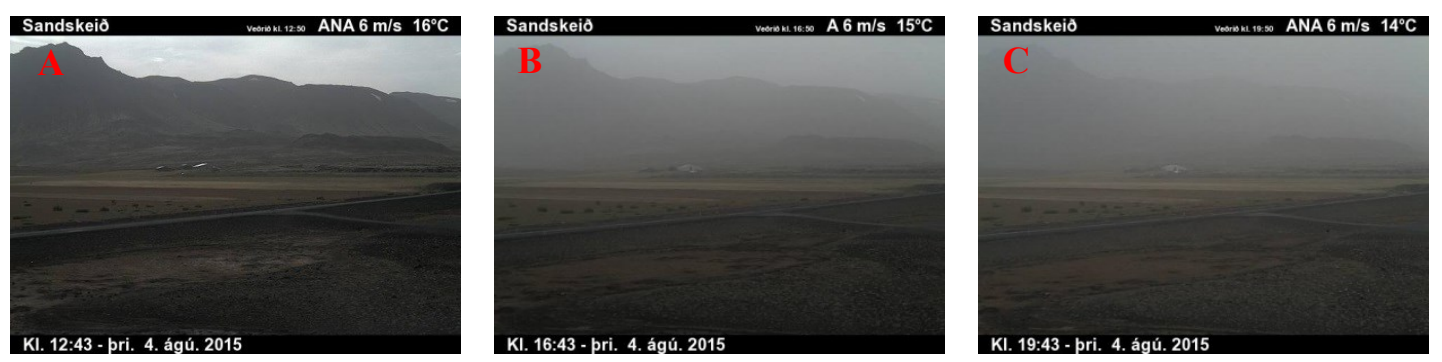

Figure 4. Changes in visibility during Storm 2 on 4 August 2015 when dust was blowing from Hagavatn. Left photo (A) shows visibility $>3.5 \mathrm{~km}$, corresponding to $\mathrm{PM}_{10}$ of $71 \mu \mathrm{g} \cdot \mathrm{m}^{-3}$, measured by a DustTrak instrument at the site. The middle photo (B) shows visibility of about $3.5 \mathrm{~km}$ corresponding to an estimated $\mathrm{PM}_{10}$ of $370 \mu \mathrm{g} \cdot \mathrm{m}^{-3}$, while the photo on the right (C) shows about $1 \mathrm{~km}$ visibility, corresponding to an estimated $\mathrm{PM}_{10}$ of $>780 \mu \mathrm{g} \cdot \mathrm{m}^{-3}$ based on the formula from Dagsson-Waldhauserova et al. [23]. The images are from a web camera from the Icelandic Road and Coastal Administration. 

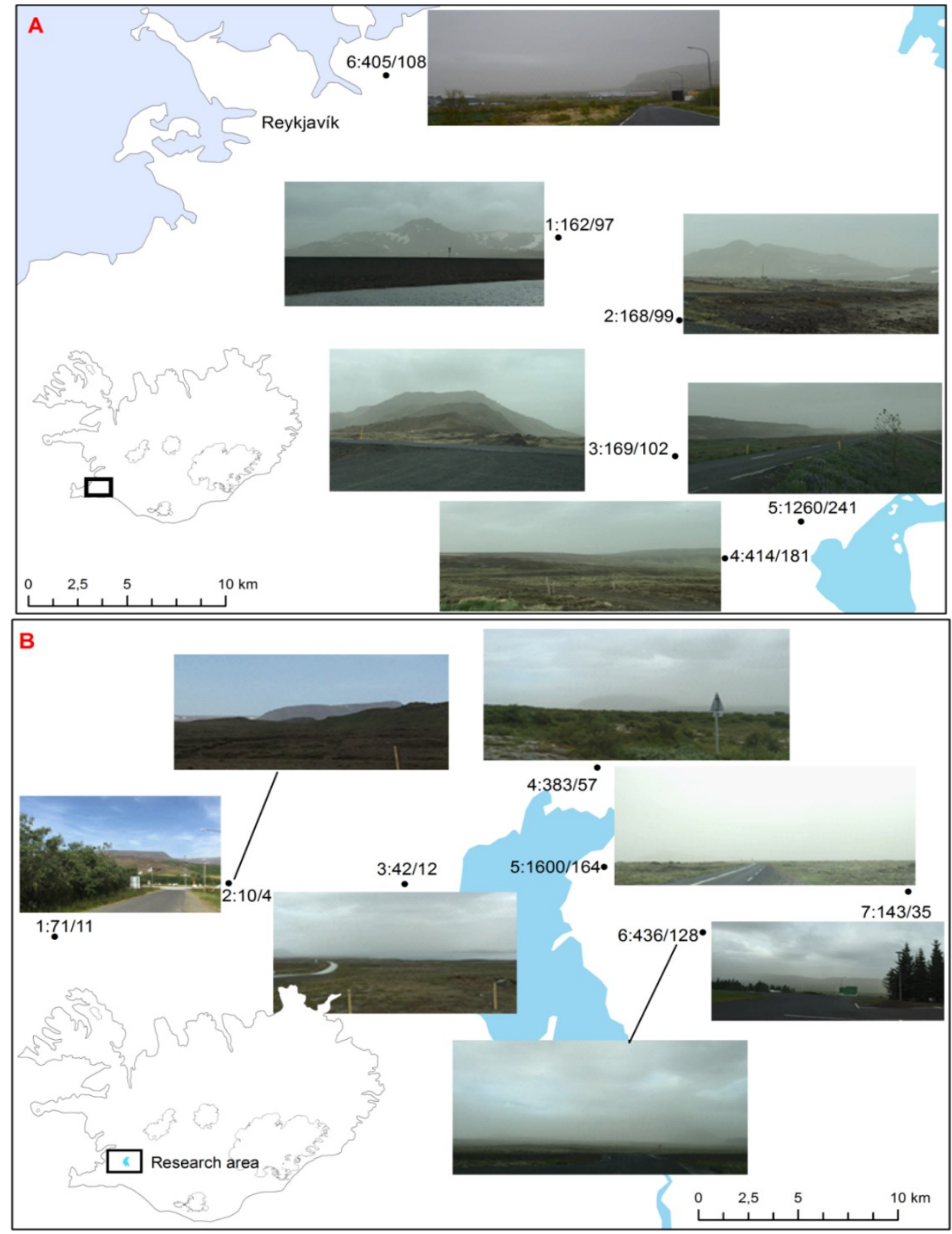

Figure 5. The measurement spots (place number: $\mathrm{PM}_{15}$ concentration $/ \mathrm{PM}_{1}$ concentration, $\mu \mathrm{g} \cdot \mathrm{m}^{-3}$ ) including a photo from every measurement spot. It can be seen that visibility was more reduced with higher dust concentrations. (A) Storm 1 from the Landeyjasandur on 15 June 2015 and (B) from Storm 2 on 4 August 2015.

Figure 6 captured how Storm 1 passed relatively densely populated areas such as the town of Hveragerði, population of 2300, and the neighboring town of Selfoss, the eighth largest community in Iceland, with about 6500 inhabitants. The highest $\mathrm{PM}_{10}$ concentrations of $>500 \mu \mathrm{g} \cdot \mathrm{m}^{-3}$ and $\mathrm{PM}_{1}>$ $200 \mu \mathrm{g} \cdot \mathrm{m}^{-3}$ were measured in this area. The margin of the dust plume is very visible on Figure 6A and it can clearly be seen how the visibility changed due to dust in the dust plume. Reduced visibility due to dust in Mosfellsbær (near Reykjavik) is shown on picture 6B. Here the concentrations exceeded $400 \mu \mathrm{g} \cdot \mathrm{m}^{-3}$ for $\mathrm{PM}_{10}$ and $100 \mu \mathrm{g} \cdot \mathrm{m}^{-3}$ for $\mathrm{PM}_{1}$. The long-term frequency of dust events in Iceland reports about one dust day annually for the capital of Reykjavik [23]. This number of dust storms is highly underestimated judging from our own observations as well as the measurements provided by 
the EAI. The meteorological stations at the towns of Hveragerði and Selfoss report 3.7 to 6.8 dust days a year.
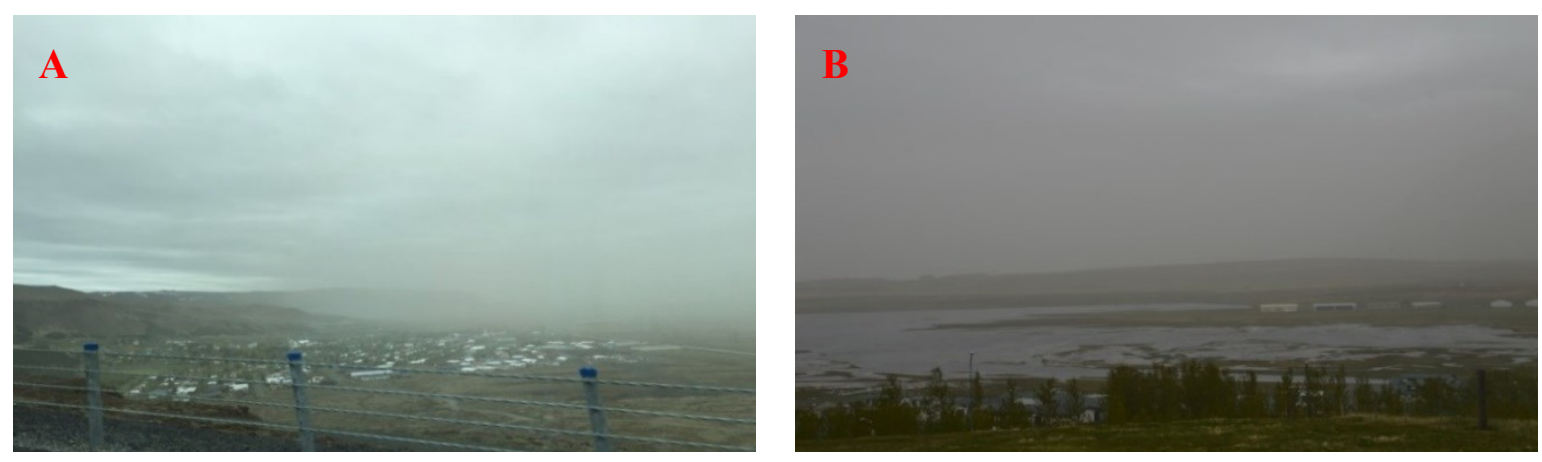

Figure 6. (A) The dust front of Storm 1 approaching to the town Hveragerði, population of 2300, which is near the town Selfoss, the eighth largest community in Iceland, with about 6500 inhabitants. The highest PM concentrations were measured in this area. The margin of the dust plume is very clear. Reduced visibility due to dust in Mosfellsbær (near Reykjavik), overlooking river Leirá, is shown on the right picture (B). Here the concentrations exceeded $400 \mu \mathrm{g} \cdot \mathrm{m}^{-3}$ for $\mathrm{PM}_{10}$ and $100 \mu \mathrm{g} \cdot \mathrm{m}^{-3}$ for $\mathrm{PM}_{1}$.

\subsection{Size Partitioning of the PM Components of Icelandic Dust}

Mineral dust outbreaks increase both fine and coarse PM concentrations [3,6,10,13,24,38,39]. Table 1 shows the mean $\mathrm{PM}_{1-15}$ concentrations at different locations (Figure 1) inside the dust plume. Although the $\mathrm{PM}_{10}$ concentrations are moderate $\left(<600 \mu \mathrm{g} \cdot \mathrm{m}^{-3}\right)$ for an ongoing dust storm in Iceland, the mean levels of $\mathrm{PM}_{1}$ are considerably high, such as $>97 \mu \mathrm{g} \cdot \mathrm{m}^{-3}$ for Storm 1 . The proportions of $\mathrm{PM}_{1} / \mathrm{PM}_{10}$ are significantly higher for Iceland than for any other dust events we have found in the literature. The $\mathrm{PM}_{1} / \mathrm{PM}_{10}$ ratio ranged from 0.41 to 0.63 for Storm 1, and 0.34 to 0.57 for Storm 2, respectively (Table 1). Perez et al. [9] reported the $\mathrm{PM}_{1} / \mathrm{PM}_{10}$ ratios were relatively stable during African dust outbreaks, where the mean annual average decreased from 0.48 to 0.42 for dust days. Arizona dust outbreaks also had even more stable $\mathrm{PM}_{1} / \mathrm{PM}_{10}$ ratios of between 0.17 and 0.22 ( 0.18 on average) [38]. Claiborn et al. [39] reported no increase in $\mathrm{PM}_{1}$ during dust storms within the USA. In Iceland, the more severe the dust event was the lower $\mathrm{PM}_{1} / \mathrm{PM}_{10}$ ratio was observed. The same trend was reported from Iran where the $\mathrm{PM}_{1} / \mathrm{PM}_{10}$ ratio decreased from 0.4 to 0.05 during the dust storms with the mean ratio of 0.14 . Generally, the $\mathrm{PM}_{1} / \mathrm{PM}_{10}$ ratio $<0.4$ is attributed to the summer season with high dust suspension as summarized from 22 studies on size-segregated particulate matter ratios [40]. These comparisons showed that Icelandic volcanic dust is extremely fine compared to the crustal dust. Such high proportions ( $>60 \%$ of $\mathrm{PM}_{1}$ in $\mathrm{PM}_{10}$ ) as obtained during Storm 1 have been reported for urban air pollution, but not for natural dust. The $\mathrm{PM}_{1}$ proportion of $57 \%-60 \%$ in $\mathrm{PM}_{10}$ was found, for example, at four sites in Austria [41] while the $\mathrm{PM}_{1} / \mathrm{PM}_{10}$ ratio between 0.45 and 0.74 was found at a polluted urban site of Taipei in Taiwan [42].

Table 1 shows that the $\mathrm{PM}_{1} / \mathrm{PM}_{2.5}$ ratio ranged from 0.89 to 0.94 , thereby confirming that most of the fine dust particles were of submicron size. This is contrary to what has been reported on such ratios during dust events elsewhere. The $\mathrm{PM}_{1} / \mathrm{PM}_{2.5}$ ratio was 0.49 during dust events in the USA [39] while the $\mathrm{PM}_{1} / \mathrm{PM}_{2.5}$ was ranging from 0.05 to 0.8 , with a corresponding mean value 0.55 , during dust storms in Iran [10]. Values such as $90 \%$ of $\mathrm{PM}_{1} / \mathrm{PM}_{2.5}$ were reported from urban sites or cities such Graz in Austria [41]. High $\mathrm{PM}_{1} / \mathrm{PM}_{2.5}$ and $\mathrm{PM}_{1} / \mathrm{PM}_{10}$ ratios imply that $\mathrm{PM}_{2.5}$ or $\mathrm{PM}_{10}$ mainly consist of submicron particles that have a greater health impact than larger particles $[6,10,12]$. Detailed mineralogical and geochemical analyses of Icelandic dust revealed fine pipe-vesicular structures of volcanic glasses, as known from asbestos and high content of heavy metals [27,28]. Such structured submicron particles can likely have even more destructive effects on human and animal health, as reported by Carlsen et al. [30]. Figures 1 and 6 illustrate that the dust plumes with high PM 
concentrations are passing the most densely inhibited areas in Iceland. The frequency of such events is up to 135 dust days annually in Iceland with many crossing populated areas [23]. Currently, no warnings for the general public are issued.

About $90 \%$ of the $\mathrm{PM}_{2.5}$ particles were attributed to submicron particle fractions, and the ratios of $\mathrm{PM}_{2.5} / \mathrm{PM}_{10}$ were similar to the $\mathrm{PM}_{1} / \mathrm{PM}_{10}$ (Table 1). The mean $\mathrm{PM}_{2.5} / \mathrm{PM}_{10}$ ratio was 0.61 for Storm 1 and 0.44 for Storm 2. This is similar to what was found during dust outbreaks in Spain [9], but considerably higher than the 0.3 ratio reported from the USA [39]. The $\mathrm{PM}_{2.5} / \mathrm{PM}_{10}$ ratios in Iran ranged from 0.1 to 0.5 with the mean of 0.23 [10]. The lower values were related to the high dust season. The high proportion of fine materials in Iceland is attributed to the small grain size at the dust sources, which is a result of glacial action producing fine-grained materials. These materials are further sorted by glacio-fluvial processes at the glacial margins and in glacial rivers [14]. This unceasing glacial and glacio-fluvial action ensures continuous re-supply of the fine grained materials, in contrast to larger aeolian bodies on the continents.

The high ratios of $\mathrm{PM}_{10} / \mathrm{PM}_{15}$ shown in Table 1 suggest a low proportion of particles $>10 \mu \mathrm{m}$. However, $<50 \%$ proportion of $\mathrm{PM}_{10}$ on $\mathrm{PM}_{15}$ in many cases suggest the presence of larger particles. We did not find any relation between the $\mathrm{PM}_{10}$ concentration and $\mathrm{PM}_{10} / \mathrm{PM}_{15}$ ratio. There is, however, limited information on this size range of PM in the literature [8].

Our results show that Icelandic dust contains fine submicron particles, as was reported by Dagsson-Waldhauserova et al. [27]. Suspended dust measured at the Mælifellssandur glacial floodplain resulted in the high proportion of close-to-ultrafine particles, such as $0.3-0.37 \mu \mathrm{m}$. Generation of such fine particles is associated with mechanical processes of glaciers and fluvial processes [27]. However, even the finest lacustrine sediments produced from the most active dust hot spots of the world, such as the Bodele Depression in the Sahara or the Sistan Basin in Iran do not consist of such high amounts of submicron particles as observed in Icelandic dust $[3,10,13,43,44]$.

\section{Conclusions}

The study of two dust events shows the usefulness of combining photos obtained by surveillance cameras and portable dust measurement instruments for identifying the extent, magnitude, and grain size characteristics of single dust storms in Iceland. It shows that common dust storms are of several hundred thousand tons of magnitude from relatively well-defined main dust sources. The in situ measurements of two moderate Icelandic dust storms in 2015 show that aeolian dust can be very fine. The study highlights that suspended volcanic dust in Iceland can have extremely high $\mathrm{PM}_{1}$ concentrations that are comparable to urban pollution in Europe or Asia. The $\mathrm{PM}_{1} / \mathrm{PM}_{2.5}$ ratios are generally low during dust storms outside of Iceland, much lower than $>0.9$ and $\mathrm{PM}_{1} / \mathrm{PM}_{10}$ ratios of $0.34-0.63$ found in our study. The extremely high proportions of submicron particles are predicted to travel long distances. Moreover, such submicron particles pose considerable health risks because of their high potential for entering the lungs. Icelandic volcanic glass often has fine pipe-vesicular structures, known from asbestos, and has a high content of heavy metals. The two dust events with high PM concentrations reported here passed the most densely inhabited areas of Iceland and influenced an area of $2450 \mathrm{~km}^{2}$ during Storm 1 and $4220 \mathrm{~km}^{2}$ in Storm 2. The mean frequency of dust events in Iceland is about 135 dust days annually, however, health risk warnings for the general public are not being issued. The data provided stresses the need for such a warning system and is an important step towards its development. In light of the small size of the dust reported here, in addition to the high frequency of the dust events, it is vital to step up integrated dust and health research in Iceland. Furthermore, dust has influence on weather and climate in general, and the fine fraction of the Icelandic dust has bearings for weather forecast and climate change predictions.

Acknowledgments: This research was funded by the Icelandic Research Fund (Rannis) Grant No. 152248-051 and the Recruitment Fund of the University of Iceland. We acknowledge the Nordic Center of Excellence (NCoE) Top Research Initiative "Cryosphere-atmosphere interactions in a changing Arctic climate" (CRAICC). 
We acknowledge that the Icelandic Road and Costal administration allowed us to use images from their web-camera network to use in this research.

Author Contributions: A.M. and O.A. conceived and designed the experiments; A.M. performed the experiments; A.M., H.O., and P.D-W. analyzed the data and contributed reagents/materials/analysis tools; P.D-W., A.M., H.O., and O.A. wrote the paper.

Conflicts of Interest: The authors declare no conflict of interest.

\section{Abbreviations}

The following abbreviations are used in this manuscript:

$\begin{array}{ll}\text { PM } & \text { Particulate matter } \\ \text { EAI } & \text { Environmental Agency of Iceland } \\ \text { IRCA } & \text { Icelandic road and coastal administration }\end{array}$

\section{References}

1. Perez, L.; Tobias, A.; Querol, X.; Künzli, N.; Pey, J.; Alastuey, A. Coarse particles from Saharan dust and daily mortality. Epidemiology 2008, 19, 800-807. [CrossRef] [PubMed]

2. Karanasiou, A.; Moreno, N.; Moreno, T.; Viana, M.; de Leeuw, F.; Querol, X. Health effects from Sahara dust episodes in Europe: Literature review and research gaps. Environ. Int. 2012, 47, 107-114. [CrossRef] [PubMed]

3. Mallone, S.; Stafoggia, M.; Faustini, A.; Gobbi, G.P.; Marconi, A.; Forastiere, F. Saharan dust and associations between particulate matter and daily mortality in Rome, Italy. Environ. Health Perspect. 2011, 119, 1409-1414. [CrossRef] [PubMed]

4. Stafoggia, M.; Zauli-Sajani, S.; Pey, J.; Samoli, E.; Alessandrini, E.; Basagaña, X.; Cernigliaro, A.; Chiusolo, M.; Demaria, M.; Díaz, J.; et al. Desert dust outbreaks in southern Europe: Contribution to daily $\mathrm{PM}_{10}$ concentrations and short-term associations with mortality and hospital admissions. Environ. Health Perspect. 2015, 124, 4. [CrossRef] [PubMed]

5. Hyewon, L.; Ho, K.; Yasushi, H.; Youn-Hee, L.; Seungmuk, Y. Effect of Asian dust storms on daily mortality in seven metropolitan cities of Korea. Atmos. Environ. 2013, 79, 510-517. [CrossRef]

6. The World Health Organization. Health Effects of Particulate Matter, Policy Implications for Countries in Eastern Europe, Caucasus and Central Asia; WHO Regional Publications European Series: Copenhagen, Denmark, 2013; p. 15.

7. Pandolfi, M.; Tobias, A.; Alastuey, A.; Sunyer, J.; Schwartz, J.; Lorente, J.; Pey, J.; Querol, X. Effect of atmospheric mixing layer depth variations on urban air quality and daily mortality during Saharan dust outbreaks. Sci. Total Environ. 2014, 494-495, 283-289. [CrossRef] [PubMed]

8. Krewski, D.; Jerrett, M.; Burnett, R.T.; Ma, R.; Hughes, E.; Shi, Y.; Turner, M.C.; Pope, C.A.; Thurston, G.; Calle, E.E.; et al. Extended follow-up and spatial analysis of the American Cancer Society study linking particulate air pollution and mortality. Res. Rep. Health Eff. Inst. 2009, 140, 5-114. [PubMed]

9. Perez, N.; Pey, J.; Querol, X.; Alastuey, A.; Lopez, J.M.; Viana, M. Partitioning of major and trace components in $\mathrm{PM}_{10}, \mathrm{PM}_{2.5}$ and $\mathrm{PM}_{1}$ at an urban site in Southern Europe. Atmos. Environ. 2008, 42, 1677-1691. [CrossRef]

10. Shahsavani, A.; Naddafi, K.; Jafarzade Haghighifard, N.; Mesdaghinia, A.; Yunesian, M.; Nabizadeh, R.; Arahami, M.; Sowlat, M.; Yarahmadi, M.; Saki, H.; et al. The evaluation of PM10, PM2.5, and PM1 concentrations during the Middle Eastern Dust (MED) events in Ahvaz, Iran, from April through September 2010. J. Arid Environ. 2012, 77, 72-83. [CrossRef]

11. Carbone, C.; Decesari, S.; Paglione, M.; Giulianelli, L.; Rinaldi, M.; Marinoni, A.; Cristofanelli, P.; Didiodato, A.; Bonasoni, P.; Fuzzi, S.; et al. 3-year chemical composition of free tropospheric PM1 at the Mt. Cimone GAW global station-South Europe-2165 m a.s.l. Atmos. Environ. 2014, 87, $218-227$. [CrossRef]

12. Colls, J.; Tiwary, A. Air Pollution Measurement, Modelling and Mitigation, 3rd ed.; Routledge: London, UK; New York, NY, USA, 2010.

13. Mahowald, N.M.; Albani, S.; Kok, J.F.; Engelstaeder, S.; Scanza, R.; Ward, S.; Flanner, M.G. The size distribution of desert dust aerosols and its impact on the Earth system. Aeol. Res. 2014, 15, 53-71. [CrossRef] 
14. Arnalds, O.; Dagsson-Waldhauserova, P.; Olafsson, H. The Icelandic volcanic aeolian environment: Processes and impacts-A review. Aeol. Res. 2016, 20, 176-195. [CrossRef]

15. Nickling, W.G. Eolian sediment transport during dust storms: Slims River Valley, Yukon Territory. Can. J. Earth Sci. 1978, 15, 1069-1084. [CrossRef]

16. Dornbrack, A.; Stachlewska, I.S.; Ritter, C.; Neuber, R. Aerosol distribution around Svalbard during intense easterly winds. Atmos. Chem. Phys. 2010, 10, 1473-1490. [CrossRef]

17. Lancaster, N.; Nickling, W.G.; Gillies, J.A. Sand transport by wind on complex surfaces: Field studies in the McMurdo Dry Valleys, Antarctica. J. Geophys. Res. 2010, 115. [CrossRef]

18. Crusius, J.; Schroth, A.W.; Gasso, S.; Moy, C.M.; Levy, R.C.; Gatica, M. Glacial flour dust storms in the Gulf of Alaska: Hydrologic and meteorological controls and their importance as a source of bioavailable iron. Geophys. Res. Lett. 2011, 38. [CrossRef]

19. Bullard, J.E. Contemporary glacigenic inputs to the dust cycle. Earth Surf. Proc. Land. 2013, 38, 71-89. [CrossRef]

20. Lamy, F.; Gersonde, R.; Winckler, G.; Esper, O.; Jaeschke, A.; Kuhn, G.; Ullermann, J.; Martinez-Garcia, A.; Lambert, F.; Kilian, R. Increased dust deposition in the Pacific Southern Ocean during glacial periods. Science 2014, 343, 403-407. [CrossRef] [PubMed]

21. Arnalds, O.; Thorarinsdottir, E.F.; Thorsson, J.; Dagsson-Waldhauserova, P.; Agustsdottir, A.M. An extreme wind erosion event of the fresh Eyjafjallajokull 2010 volcanic ash. Nat. Sci. Rep. 2013, 3, 1257. [CrossRef] [PubMed]

22. Dagsson-Waldhauserova, P.; Arnalds, O.; Olafsson, H. Long-term frequency and characteristics of dust storm events in Northeastern Iceland (1949-2011). Atmos. Environ. 2013, 77, 117-127. [CrossRef]

23. Dagsson-Waldhauserova, P.; Arnalds, O.; Olafsson, H. Long-term variability of dust events in Iceland (1949-2011). Atmos. Chem. Phys. 2014, 14, 13411-13422. [CrossRef]

24. Thorsteinsson, T.; Gisladottir, G.; Bullard, J.; McTainsh, G. Dust storm contributions to airborne particulate matter in Reykjavík, Iceland. Atmos. Environ. 2011, 45, 5924-5933. [CrossRef]

25. The World Health Organization. Air Quality Guidelines Global Update 2005. In Proceedings of the Report on a Working Group Meeting, Bonn, Germany, 18-20 October 2005.

26. The Environment Agency of Iceland. Air Quality in Iceland. Available online: http:/ / ust.is/the-environmentagency-of-iceland/ (accessed on 14 February 2016).

27. Dagsson-Waldhauserova, P.; Arnalds, O.; Olafsson, H.; Skrabalova, L.; Sigurdardottir, G.; Branis, M.; Hladil, J.; Skala, R.; Navratil, T.; Chadimova, L.; et al. Physical properties of suspended dust during moist and low-wind conditions in Iceland. Icel. Agric. Sci. 2014, 27, 25-39.

28. Dagsson-Waldhauserova, P.; Arnalds, O.; Olafsson, H.; Hladil, J.; Skala, R.; Navratil, T.; Chadimova, L.; Meinander, O. Snow-dust storm: A case study from Iceland, 7 March 2013. Aeol. Res. 2015, 16, 69-74. [CrossRef]

29. Baratoux, D.; Mangold, N.; Arnalds, O.; Bardintzeff, J.M.; Platevoet, B.; Gregorie, M.; Pinet, P. Volcanic sands of Iceland-Diverse origins of Aeolian sand deposits revealed at Dyngjusandur and Lambahraun. Earth Surf. Proc. Land 2011, 36, 1789-1808. [CrossRef]

30. Carlsen, H.K.; Gislason, T.; Forsberg, B.; Meister, K.; Thorsteinsson, T.; Johannsson, T.; Finnbjornsdottir, R.; Oudin, A. Emergency hospital visits in association with volcanic ash, dust storms and other sources of ambient particles: A time-series study in Reykjavík, Iceland. Int. J. Environ. Res. Public Health 2015, 12, 4047-4059. [CrossRef] [PubMed]

31. Blechschmidt, A.-M.; Kristjansson, J.E.; Olafsson, H.; Burkhart, J.F.; Hodnebrog, Ø. Aircraft-based observations and high-resolution simulations of an Icelandic dust storm. Atmos. Chem. Phys. 2012, 12, 7949-7984. [CrossRef]

32. Branis, M.; Hovorka, J. Performance of a photometer DustTrak in various indoor and outdoor environments. In Proceedings of the Abstracts of the 2005 Evaluations and Assessment Conference (EAC 2005), Ghent, Belgium, 28 September-10 October 2005; p. 535.

33. Wallace, L.A.; Wheeler, A.J.; Kearney, J.; Van Ryswyk, K.; You, H.; Kulka, R.H.; Rasmussen, P.E.; Brook, J.R.; $\mathrm{Xu}, \mathrm{X}$. Validation of continuous particle monitors for personal, indoor, and outdoor exposures. J. Expo. Sci. Environ. Epidemiol. 2011, 21, 49-64. [CrossRef] [PubMed]

34. The Icelandic Road and Coastal Administration. Road, Web Cameras. Available online: http://www.road.is/ travel-info/web-cams/ (accessed on 4 August 2015). 
35. Pey, J.; Rodríguez, S.; Querol, X.; Alastuey, A.; Moreno, T.; Putaud, J.P.; Van Dingenen, R. Variations of urban aerosols in the western Mediterranean. Atmos. Environ. 2008, 42, 9052-9062. [CrossRef]

36. Theodosi, C.; Grivas, G.; Zarmpas, P.; Chaloulakou, A.; Mihalopoulos, N. Mass and chemical composition of size-segregated aerosols $\left(\mathrm{PM}_{1}, \mathrm{PM}_{2.5}, \mathrm{PM}_{10}\right)$ over Athens, Greece: Local versus regional sources. Atmos. Chem. Phys. 2011, 11, 11895-11911. [CrossRef]

37. Arnalds, O.; Olafsson, H.; Dagsson-Waldhauserova, P. Quantification of iron rich volcanogenic dust emissions and deposition over ocean from Icelandic dust sources. Biogeosciences 2014, 11, 6623-6632. [CrossRef]

38. Lundgren, D.A.; Hlaing, D.N.; Rich, T.A.; Marple, V.A. PM10/PM2.5/PM1.0 data from a trichotomous sampler. Aerosol Sci. Tech. 1996, 25, 353-357. [CrossRef]

39. Claiborn, C.S.; Finn, D.; Larson, T.; Koenig, J. Windblown dust contributes to high $\mathrm{PM}_{2.5}$ concentrations. J. Air Waste Manag. Assoc. 2000, 50, 1440-1445. [CrossRef] [PubMed]

40. Speranza, A.; Caggiano, R.; Margiotta, S.; Summa, V.; Trippett, S. A clustering approach based on triangular diagram to study the seasonal variability of simultaneous measurements of PM10, PM2.5 and PM1 mass concentration ratios. Arab. J. Geosci. 2016, 9, 132. [CrossRef]

41. Gomišček, B.; Hauck, H.; Stopper, S.; Preining, O. Spatial and temporal variation of PM1, PM2.5, PM10 and particle number concentration during the AUPHEP-project. Atmos. Environ. 2004, 38, 3917-3934. [CrossRef]

42. Li, C.-S.; Lin, C.-H. $\mathrm{PM}_{1} / \mathrm{PM}_{2.5} / \mathrm{PM}_{10}$ Characteristics in the urban atmosphere of Taipei. Aerosol Sci. Technol. 2002, 36, 469-473. [CrossRef]

43. Todd, M.C.; Washington, R.; Martins, J.V.; Dubovik, O.; Lizcano, G.; M’Bainayel, S.; Engelstaedter, S. Mineral dust emission from the Bodélé Depression, northern Chad, during BoDEx 2005. J. Geophys. Res. 2007, 112. [CrossRef]

44. Kaskaoutis, D.G.; Rashki, A.; Houssos, E.E.; Goto, D.; Nastos, P.T. Extremely high aerosol loading over Arabian sea during June 2008: The specific role of the atmospheric dynamics and Sistan dust storms. Atmos. Environ. 2014, 94, 374-384. [CrossRef]

(C) 2016 by the authors; licensee MDPI, Basel, Switzerland. This article is an open access article distributed under the terms and conditions of the Creative Commons Attribution (CC-BY) license (http://creativecommons.org/licenses/by/4.0/). 